\title{
UWAGI NA TEMAT INAUGURAL SPEECH JOE BIDENA JAKO AKTU RETORYCZNEGO W ŚWIETLE KLASYCZNEJ TEORII RETORYKI
}

\author{
KRYSTYNA TUSZYŃSKA
}

\begin{abstract}
The article performs an analysis of $46^{\text {th }}$ USA President's inaugural speech in the spirit of Neo-Aristotelian concepts. The article also contains an analysis of inaugural speech genre, matching Joe Biden's case as a hybrid, and analyses elocutio and the way the speaker claims the space of communication. The article also refers to Aristotle's concept of ethos.
\end{abstract}

Key words: display rhetoric and deliberative rhetoric, hybrid genre of rhetoric, Aristotelian ethos, rhetorical analysis, space of communication, inaugural speech as a spectacle

\section{Inaugural speech jako spektakl going public}

Mowa inauguracyjna prezydenta Stanów Zjednoczonych Ameryki jest w analizach retorycznych gatunkiem wymagającym. Zasadnicze dwie strategie zmierzają w kierunku spojrzenia na nią bądź pragmatycznie, tzn. ze skupieniem uwagi na sposobie wystąpienia w wymiarze politycznym, bądź, wedle neoarystotelesowskich klasycznych teorii retoryki, z położeniem nacisku na wartości semantyczne i syntaktyczne, sprowadzane do treści i formy mowy ${ }^{1}$. Spojrzenie na mowę inauguracyjną

\footnotetext{
${ }^{1}$ Analiza gatunków mowy prezydenckiej, jak mowa inauguracyjna czy orędzie o stanie państwa jest przedmiotem badań interdyscyplinarnych, badaczy komunikacji językowej i politologów. Anna Bendrat uważa, że poddana analizie wypowiedź należąc do dyskursu otwartego i zorganizowanego wokół konkretnej sytuacji retorycznej może generować spojrzenie pragmatyczne (mowa jako forma działania retorycznego) w przeciwieństwie do syntaktycznego (forma wypowiedzi) lub semantycznego (treść wypowiedzi), charakterystycznych dla badań literackich. Zob. Anna Bendrat, Mowa jest złotem. Amerykański prezydent i retoryka, Olsztyn 2016, s. 230.
} 
w jej wymiarze politycznym charakterystyczne jest dla podejścia amerykańskiego wobec badań nad retoryką prezydenta USA, podczas gdy koncepcje neorystotelesowskie znajdują się zasadniczo $\mathrm{w}$ polu badań europejskich. W artykule pójdę tą właśnie „klasyczną” ścieżką, koncentrując uwagę na czterech wymiarach retoryki, inventio, dispositio, elocutio oraz actio ${ }^{2}$. Uznaję jednak za konieczne krótkie scharakteryzowanie inaugural speech jako spektaklu politycznego, ponieważ charakterystyka taka wspomaga interpretację specyfiki tejże mowy, także według podejścia neoarystotelesowskiego. Poza tym, uważam, że nawet $\mathrm{w}$ pracach utrzymanych w duchu klasycznej analizy retorycznej spotykamy się z brakiem zrozumienia Arystotelesowskiego terminu ethos, w wyniku interpretowania go jako „reputacji”, „opinii o mówcy”. Jest to błędem w świetle koncepcji triady Arystotelesa z jego Retoryki (1356a 1-5). Odniosę się do tych zagadnień pod koniec pierwszej części artykułu.

Politolog Samuel Kernell w książce Going Public: New Strategies of Presidential Leadership przedstawił transformację modelu komunikacji perswazyjnej prezydenta USA w wyniku rozwoju środków technologicznych, za których sprawą perswazja prezydencka $\mathrm{z}$ negocjacji w zamkniętym kręgu Kongresu przerodziła się w spektakl polityczny skierowany do mas, podporządkowany sile przekazu strony wizualnej/performatywnej ${ }^{3}$. Tym samym wypracowany został nowy model wystąpień prezydenckich, going public, stanowiący „strategię, zgodnie z którą prezydent promuje sam siebie oraz swoją politykę, zabiegając o poparcie bezpośrednio u amerykańskiej opinii publicznej”’4. Wspomagające propozycję Kernella dotyczącą spektaklu medialnego w miejsce negocjacji/ dysputy, w której należy liczyć się z natychmiastową reakcją oponenta, są badania Kennetha Burke'a nad analogią mechanizmów rządzących perswazją nacechowaną emocjonalnie do mechanizmów uwalniania się afektów w dramacie antycznym ${ }^{5}$. Aprobując tę strategię badań mogę dodać, że dramat starogrecki przetwarzając mit lub wykorzystując go jako „punkt zaczepienia” wkraczał nie tylko w sferę przeżyć emocjonalnych publiczności, doprowadzając do momentu katharsis, ale także posiadał funkcję opiniotwórczą: publiczność zwykła przyjmować społeczno-ideologiczny wyraz tragedii lub go odrzucać ${ }^{6}$. Kilka przy-

\footnotetext{
${ }^{2}$ Pomijam ze względów zrozumiałych (nieznajomość technik mnemonicznych Joe Bidena), dział zwany memoria.

${ }^{3}$ Dla Kernella (Going Public: New Startegies of Presidental Leadership, Washington 2006) zasadnicza zmiana formy i jakości komunikacji prezydenta USA polegała na pominięciu Kongresu oraz oparciu opinii o jakości przywództwa na sposobie i częstotliwości wystąpień publicznych, a nie na jakości i treści wystąpień traktowanych jako akty retoryczne. Za A. Bendrat, op. cit., s. 182.

${ }^{4}$ S. Kernell, op. cit., s. 5.

${ }^{5}$ A. Bendrat powołuje się na hasło Dramatism opracowane przez K. Burke'a w: International Encyclopedia of the Social Science, New York 1968, s. 445.

${ }^{6} \mathrm{~W}$ teatrze greckim tetralogie (trylogia i dramat satyrowy) były poddawane osądowi sędziów z tzw. fyli attyckich. Dziesięciu sędziów z dziesięciu fyli wydawało werdykt odnośnie trzech stających do konkursu tragików z ich tetralogiami.
} 
kładów: w trylogii Oresteia Ajschylosa dwie pierwsze tragedie, Agamemnon i Ofiarnice wykorzystują cykl mitów trojańskich, podczas gdy ostatnia, Eumenidy, kluczowa dla zrozumienia przesłania Ajschylosa - pochwały dla instytucji sądowniczych demokratycznych Aten, stanowi własną wizję poety, opowiadającego się za ładem demokratycznym w miejsce krwawej wendetty (Ajschylos zwyciężył tą trylogią konkurs na Dionizjach Wielkich w 458 r. p.n.e.); w komedii Arystofanesa Żaby pada dewiza funkcji teatru: „czym dla dzieci szkoła, tym dla dorosłych teatr, dobra powinien nauczać". Zatem, abstrahując od afektów generowanych przez katharsis, teatr rzeczywiście pełnił funkcję ideologiczną, opiniotwórczą, a tym samym wskazanie na powinowactwo dramatu i aktu perswazyjnego jest w pełni uzasadnione, jak pokazuje to termin Victora Turnera - social drama.

Umberto Eco szukając z kolei analogii między retoryką a ideologią, przez którą rozumie ,całokształt wiedzy adresata i grupy, do której adresat należy, jego system oczekiwań psychologicznych, jego postawy myślowe, jego nabyte doświadczenia, jego zasady moralne"7, zauważa, że jednostka musi zdawać sobie sprawę, że będzie efektywnie komunikatywna, rozpoznawalna, gdy jej system wiedzy stanie się systemem znaków, sama zaś ideologia uspołeczniwszy się stanie się kodem, widzialnym, sprawdzalnym ${ }^{8}$. Nadto, co ważne w kontekście ,spektaklu dla mas” zaślubiny form retorycznych z motywacjami ideologicznymi dokonują się również, jak uważa Eco ${ }^{9}$, w dziedzinie znaków wzrokowych. Powrócę do tego spostrzeżenia Eco przy analizie obudowy artystycznej ceremoniału towarzyszącego inaugural speech Joe Bidena w ostatniej części artykułu.

Sięgając do rozważań Arystotelesa nad powinowactwem sztuki wygłoszenia mowy, a zatem aspektu performatywnego retoryki, do spektaklu teatralnego, należy wskazać, iż Stagiryta doskonale zdawał sobie sprawę z rangi wygłoszenia mowy, gr. hypokrisis, łac. actio, dla osiągnięcia sukcesu perswazyjnego i odsyłał w Retoryce zainteresowanych do kształcenia się u aktorów: „Kiedy sztuka deklamacji zostanie wykształcona, mówcy będą osiągać te same efekty, co teraz aktorzy"10. Uważał też, ze względu na pojawiające się w owych czasach próby opracowania przez sofistów technik wzruszania (1404a 15), że kunszt aktorski wymyka się naukowym badaniom. Jednak, Demostenes, największy mówca starożytnej Grecji, wedle anegdoty, pytany, jaka cześć retoryki jest najważniejsza, odpowiadał hypokrisis, a indagowany o drugą w kolei, ponawiał odpowiedź - hypokrisis, podobnie jak pytany o trzecią najważniejszą cześć sztuki retorycznej ${ }^{11}$.

\footnotetext{
${ }^{7}$ U. Eco, Struktura nieobecna, przeł. A. Weisberg, P. Bravo, Warszawa 1996, s. 109.

${ }^{8}$ Idem, s. 110.

${ }^{9}$ Idem, s. 111.

${ }^{10}$ Arystoteles, Retoryka, 1404a 10, przekład (ten i kolejne) wg: Arystoteles, Retoryka. Poetyka, przełożył, wstępem i komentarzem opatrzył H. Podbielski, Warszawa 1988.

${ }^{11}$ Zob. też artykuł: K. Tuszyńska-Maciejewska, Arystotelesowskie wskazówki dla aktorów, czyli o przenikaniu się sztuk, „Meander” 5/6, 2002.
} 
Tych kilka dość luźnych uwag ma na celu zwrócenie uwagi, iż neoarystotelesowska interpretacja występu publicznego nie jest bynajmniej aż tak daleka od rozpatrywania mowy inauguracyjnej prezydenta Stanów Zjednoczonych jako spektaklu, w którym prezydent obejmujący władzę staje się protagonistą teatru dla mas, a sam spektakl nośnikiem ideologii.

Odniosę się też do nieporozumień, jakie narosły wokół interpretacji pojęcia ethos u Arystotelesa. Nawet w uznanych tekstach analizujących wystąpienia prezydentów Stanów Zjednoczonych ${ }^{12}$, krytycznie nastawionych do analiz retorycznych jako pozwalających zrozumieć dyskurs polityczny, pojawia się oddanie ethosu Arystotelesa przez termin „reputacja”. Nic bardziej mylnego. Grecki rzeczownik ethos przechodził rzeczywiście długą drogę określania zakresu semantycznego, wycho-

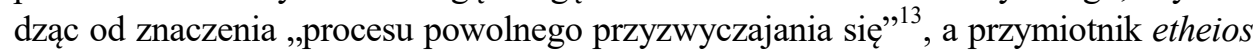
wyrażał u Homera zażyłość między ludźmi, płynącą ze wspólnego obcowania. Czasownik ethidzo w znaczeniu „przyzwyczajam” potwierdzony jest u Platona w Prawach (792a), u Arystotelesa w Etyce Nikomachejskiej (1103a 17), Polityce (1339a 21). Dla ścisłości należy zaznaczyć, iż ethos ma dwa zakresy semantyczne: moralny i stylistyczny, przy czym ten ostatni dotyczy leksis ethike, czyli „stylu etycznego", który powinien uwzględnić stosowność (prepon) i ujawnić postanowienie, intencję mówcy (proairesis). Turasiewicz stoi na stanowisku, że „postanowienie” nie jest identyczne z ,przekonaniem”. Mówca wypracowując swój ethos w mowie dokonuje pewnych wyborów argumentacyjnych i stylistycznych, które dopiero generują w trakcie wystąpienia „charakter” mówcy. W tej słusznej interpretacji greckiego pojęcia Turasiewicz powołuje się na wybitną pracę W.F.R. Hardie'go Aristotle's Ethical Theory, Oxford 1968 (s. 165), w której uczony pisze: "Choice is an indication of character but opinion is not". Postanowienie (proiaresis), które jest ściśle związane z dzielnością etyczną, stanowi lepszy sprawdzian wartości etycznej człowieka i jego charakteru niż jego czyny ${ }^{14}$. Pojęcie ethos w Retoryce Arystoteles wiąże ze sferą myślenia i intelektu (dianoia) ${ }^{15}$. W triadzie Arystotelesa ethos (obok pathos) ma wagę retorycznego środka przekonywania, należącego do „sztuki jako takiej”, co oznacza, że musi być wypracowany przez mówcę, a nie mu dany a priori, co sugerować mogłyby pojęcia „reputacja”, „opinia o mówcy” pojawiające się we współczesnych opracowaniach. Ethos należy do kategorii entechnoi pisteis (1356a 2), chociaż obok istnieją atechnoi pisteis, czyli środki wykorzystywane w perswazji, ale

${ }^{12}$ Mam na myśli esej Richarda A. Joslyna Keeping Politics in the Study of Political Discourse, omawiany przez A. Bendrat w jej książce (m.in. s. 255). Fragment zdania: „Czy ocena elokwencji prezydenta na podstawie jego reputacji, a nie reakcji audytorium jest miarodajna?"

${ }^{13}$ Romuald Turasiewicz, Od ethosu do ethopoii. Studia z antycznej terminologii krytyczno-literackiej u Dionizjusza z Halikarnasu, Zeszyty Naukowe UJ, CCCII, Prace historyczno-literackie, Kraków 1975, s. 17.

${ }^{14}$ Idem, s. 30.

${ }^{15}$ Podobnie Arystoteles rozumuje w Poetyce: ethos i dianoia pojawiają się w znaczeniu właściwości działających osób i razem determinuję charakter ich postępowania. 
nienależące do sztuki. Turasiewcz zdecydowanie stoi na tym stanowisku, kiedy pisze: „Mówca musi wywołać korzystne wrażenie przez swoją mowę, a nie dzięki dobrej opinii o swym charakterze, uprzednio już przyjętej przez ogół"16. Dobitnie tę różnicę podkreślają także późniejsi retorzy, idący śladem koncepcji Arystotelesa. Warto przytoczyć wyjaśnienie anonimowego retora Techne rhetorike (Anonymus Graeveni):

„Prostymi (atechnoi) są nazywane te środki dowodzenia, przy których nie ma potrzeby przygotowania ze strony mówcy, a które nawet człowiek nie posiadający wykształcenia retorycznego potrafi wynaleźć. Przy prostych środkach dowodzenia zadaniem mówcy jest rzeczom dla niego korzystnym nadać jak największe znaczenie, te zaś, które są niekorzystne umniejszyć i przedstawić jako zgoła nie zasługujące na wiarę"17.

Podobnie rzecz przedstawia się u późniejszego retora Minukianosa ${ }^{18}$, który uważa, że proste środki (atechnoi) nie wymagają żadnej sztuki od mówcy, chyba tylko tej, że trzeba je umieć zastosować w odpowiednim momencie. Natomiast, zdaniem Minukianosa, „sztuczne” środki (entechnoi), jak ethos, wymagają inwencji i ekonomii w połączeniu ze sztuką.

Słusznym zatem staje się postawienie pytania, skąd owo mylne rozumienie pojęcia ethos? Nasuwa mi się jedno wytłumaczenie, a mianowicie, że źródło błędnego interpretowania koncepcji i terminologii Arystotelesa leży w przyjęciu za podobną, bądź identyczną koncepcję Izokratesa, znanego nauczyciela retoryki, proponującego retoryczny model wykształcenia, który na wieki utrwalił się w Europie, wypierając model filozoficzny, proponowany przez Platona w Akademii. Dla Izokratesa ethos mówcy był równoznaczny z doksa tou legontos, czyli opinią o mówcy, dobrą sławą, towarzyszącą mu, gdy podejmuje się przemawiać w sprawach ważnych, interesujących ogół i pożytecznych ${ }^{19}$. Tymczasem koncepcja Arystotelesa jest wymierzona przeciw Izokratejskiej:

„Isocrates is most highly spoken of in the Phaedrus, but his relations to Aristotle were, according to ancient authorities, the reverse of friendly. The chief reason for this seems to have been that Aristotle had started a school of Rhetoric, which threatended to endanger the popularity of that of his older rival. [...] Further, Aristotle had attacked Isocrates, either in the Gryllus or the treatise on the different „Arts” of rhetoric, which called forth a lengthy replay from Cephisodorus, one of the pupils of Isocrates, in which various theories of Aristotle were criticized, and the philosopher himself stigmatized as a drunkard and a gourmandizer ${ }^{20}$.

\footnotetext{
${ }^{16}$ R. Turasiewicz, op. cit., s. 33 .

${ }^{17}$ Rhetores Graeci, I, s. 378, 145 ed. Spengel-Hammer. Przekład R. Turasiewicza, op. cit., s. 33 przypis 21 .

${ }^{18}$ Rhetores Graeci I, s. 340, 1, ed. Spengel-Hammer.

${ }^{19}$ Zob. Pierre Hadot, Arts liberaux et philosophie dans la pensie antique, Paris 1984, s. 16.

${ }^{20}$ Aristotle, The Art of Rhetoric, with an English translation by John Henry Freese, Cambridge 1975, s. xxvii-xxxviii (introcution).
} 
Niemałe znaczenie w błędnej interpretacji arystotelesowskiego ethos ma również ubożyzna języka łacińskiego, na którą narzeka Kwintylian nie potrafiąc precyzyjnie oddać ethosu Arystotelesa w Institutio oratoria: Cuius nomine caret sermo Romanus (VI, 2,8), Cyceron zaś wielokrotnie sięga po prostu po terminy greckie, nie znajdując odpowiednika w rodzimej łacinie.

Podsumowując zatem, arystotelesowski ethos jest prawdziwym crux philologorum, a niewczytanie się $\mathrm{w}$ grecki oryginał Retoryki Arystotelesa prowadzi do thumaczenia i interpretowania ethosu jako „reputacji”, „opinii” towarzyszących publicznym wystąpieniom, w tym też wystąpieniom prezydentów USA. Zagadnienie jest ważne z punktu widzenia traktowania inaugural speech jako spektaklu dla publiczności, zarówno zgromadzonej na uroczystości przed Kapitolem, jak też śledzącej wydarzenie w telewizji czy Internecie. Mowa inauguracyjna należy do bardzo trudnych mów, ponieważ prezydent obejmujący urząd zmienia swój wizerunek w trakcie mowy z wizerunku znanego Amerykanom w kampanii wyborczej, której język wystąpień jest bardziej dobitny i nastawiony na pokazanie różnic swojej wizji Ameryki wobec tejże wizji kontrkandydata na urząd prezydencki, na wizerunek ,prezydenta wszystkich Amerykanów”. Jak słusznie zauważa A. Bendrat, prezydent wykorzystuje narzędzia spektaklu do projekcji jak najbardziej uniwersalnego wizerunku ${ }^{21}$. Znaczy to ni mniej ni więcej, że prezydent w trakcie mowy inauguracyjnej buduje swój nowy/inny wizerunek, wykazując się życzliwością, zdrowym rozsądkiem ${ }^{22}$, a tym samym starając się pozyskać w czasie wystąpienia tych obywateli, którzy oddali głos na jego przeciwnika. Nie ma zatem wątpliwości, że w trakcie inaugural speech buduje swój ethos, a nie przystępuje do wygłoszenia mowy z pewną reputacją.

\section{Inaugural speech $\mathbf{w}$ świetle sporu o gatunek retoryczny}

Badacze retoryki prezydentów amerykańskich prowadzą spór na temat gatunków retorycznych prezydenckich wystąpień, podążając dwoma torami: politologiczno-retorycznym, w którym największe osiągnięcia należą do Karlyn Kohrs Campbell i Kathleen Jamieson ${ }^{23}$ oraz torem kwestionującym zasadność teorii gatunków w badaniach nad retoryką prezydencką. Bendrat podaje przykład znawcy politologicznej koncepcji prezydentury retorycznej, Arthura Schlesingera ${ }^{24}$, który uważa za bezcelowe badanie mowy inauguracyjnej, ponieważ stanowi ona formę podrzędną, rzadko będąc źródłem inspirujących refleksji, pełną frazesów, pompatycznej retory-

\footnotetext{
${ }^{21}$ A. Bendrat, op. cit. s. 221.

${ }^{22}$ Arystoteles wymienia trzy zalety dobrego mówcy: phronesis, arete, eunoia (1378a 5).

${ }^{23}$ Mam na myśli ich książkę Presidents Creating Presidency: Deeds Done in Words, Chicago 2008.

${ }^{24}$ Książka The Chief Executive: Inaugural Address of the President of United States from George Washington to Lyndon B. Johnson, New York 1965.
} 
ki, obsesyjnie związanej z rytuałem przejęcia władzy. Bendrat przybliża koncepcję badaczek Campbell i Jamieson, wyliczając wyznaczniki gatunkowe mowy inauguracyjnej $^{25}$, którą badaczki zaliczają do retoryki epideiktycznej, czyli okolicznościowej, a tej źródeł należy szukać w czasach I sofistyki greckiej (V i IV w. p.n.e.). Teoria gatunkowa jako metoda nadań nad retoryką prezydencką jest krytykowana też przez wspomnianego już politologa Richarda A. Joslyna, zdaniem którego analizy retoryczne nie są odpowiedzią na procesy polityczne, w szczególności dyskurs politycz$n^{26}$. Jego wątpliwości dotyczą również nie zawsze symetrycznie występujących w mowach inauguracyjnych elementów, na których Campbell i Jamieson budują swoją teorię, takich jak zjednoczenie narodu, wspólne wartości, filozofia polityczna i legitymizacja władzy. Po drugie, jego zdaniem, pojedyncze cechy preferowanej przez badaczki w analizie inagural speech retoryki epideiktycznej pojawiają się też w innego typu wystąpieniach prezydenckich, jak orędzie o stanie państwa czy niektóre mowy w trakcie kampanii. Można uznać, że dla Joslyna kryteria przyjęte przez Campbell i Jamieson nie są wystarczająco ostre.

Spór o gatunek prowokuje do przyjrzenia się mowie inauguracyjnej prezydenta Stanów Zjednoczonych w świetle koncepcji neoarystotelesowskich. Chcę poszerzyć nieco perspektywę spojrzenia na retorykę grecką okresu ateńskiego oświecenia i zarysować punkty styczne między współczesnym gatunkiem a starożytnością, jak również nieco zmodernizować teorię Campbell i Jamieson pod kątem przynależności gatunkowej inaugural speech, wprowadzając pojęcie "gatunku hybrydycznego" w tym jednym konkretnym przypadku, mowy inauguracyjnej Bidena.

W dniu 20 stycznia 2021 roku Joseph Biden Jr. został zaprzysiężony na 46. Prezydenta USA. Inauguracja nowego prezydenta jest dla obywateli Ameryki „mszą koronacyjną demokracji” ${ }^{27}$, której towarzyszy drobiazgowy ceremoniał, co sugeruje, że mowa inauguracyjna prezydenta plasuje się wśród tzw. mów okolicznościowych (genos epidektikon) Tym też tropem poszły Campbell i Jamieson zaliczając inaurual speech do retoryki epideiktycznej, mając na uwadze bezpośredni związek mowy z uroczystą okazją, w której przeszłość i przyszłość łączą się w teraźniejszej kontemplacji, zachętę do refleksji nad tradycyjnymi wartościami, ozdobny stylistycznie język, „kumulację efektu” poprzez podkreślenie tego, co ogólnie wiadome i powszechnie uznane, opiewanie zasad nowej administracji ${ }^{28}$.

Odniosę się najpierw do podobnych gatunków retorycznych w starożytności greckiej, pod względem połączenia elementów retoryki epideiktycznej z nakreśleniem projekcji polityki zewnętrznej i wewnętrznej, potem zaś do „kumulacji efektu”

\footnotetext{
${ }^{25}$ A. Bendrat, op. cit, s. 241-266.

${ }^{26}$ Eadem, s. 255.

${ }^{27}$ Określenie użyte przez polskiego dziennikarza komentującego uroczystość zaprzysiężenia, Piotra Kraśko.

${ }^{28}$ Dla szerszego spojrzenia na podziały dokonywane przez autorki w zakresie gatunków retoryki wg klasyfikacji Arystotelesa zob. A. Bendrat, op. cit., s. 231-266.
} 
i „zasad nowej administracji” w świetle sytuacji, w jakiej Joe Biden wygłaszał mowę inauguracyjną.

W rodzaju okolicznościowym (epideiktycznym, tzn. pokazowym ${ }^{29}$ ) niejako na widok publiczny wystawiony zostaje zarówno talent retoryczny mówcy, co jakość podejmowanego przez niego tematu. Osądowi słuchacza podlega nie tylko stopień umiejętności performatywnych osoby wygłaszającej przemowę, ale również pobudki, jakie kierują mówcą w podjęciu i opracowaniu tematu, tym samym osądowi podlega postawa etyczna mówcy, jego ethos, podniesiony przez Arystotelesa do rangi retorycznych środków przekonywania. Mowa okolicznościowa staje się w świetle wywodu Arystotelesa „papierkiem lakmusowym” ethosu mówcy, o czym była już mowa.

Arystoteles wskazuje również na sposobność wykorzystania przez mówcę w rodzaju okolicznościowym topiki mowy doradczej/politycznej (1368a 1-10), ponieważ wyrażając dany sąd aksjologiczny w mowie okolicznościowej przez zmianę kształtu formy językowej doradzamy słuchaczom lub odradzamy działania i zachowania:

„Kiedy więc chcesz kogoś pochwalić, zastanów się, jakiej mógłbyś udzielić mu rady, i odwrotnie, jeśli chcesz mu udzielić jakiejś rady, zastanów się, za co mógłbyś ją pochwalić. Forma językowa musi oczywiście otrzymać inny kształt [...]”.

Już starożytni teoretycy wymowy dostrzegli możliwości połączenia w jednym, hybrydycznym, gatunku mowy okolicznościowej z mową polityczną. Izokrates stał na stanowisku, iż w mowie epideiktycznej mówca ma prawo do czerpania hojną ręką z arsenału ozdobności retorycznej, określonej później łacińskim terminem ornatus. Ten sam Izokrates w znacznej części swojej bogatej spuścizny retorycznej posługiwał się hybrydycznym gatunkiem retoryki, łączącym walory epideiktyczne z przesłaniem politycznym ${ }^{30}$. Ideał sztuki bliskiej Izokratesowi streścił celnie M. Korolko:

„Tylko prawda zawarta w słowie i jego waga moralna przesądza o sile i skuteczności argumentacji, zaś szata zewnętrzna jest jedynie pożądanym i zawsze funkcjonalnym środkiem pomocniczym"31.

${ }^{29}$ Stosuję termin „pokazowy” za sugestią Jerzego Ziomka (Retoryka opisowa, Ossolineum, Wrocław 1990, s. 31), iż polski przymiotnik ,popisowy” nie oddaje w pełni greckiego przymiotnika epideiktikon, w którego rdzeniu słownym zawarte jest „wystawianie na widok publiczny”, „stawianie przed oczyma”. Retoryka epideiktyczna skupiała się, wg Arystotelesa, na pochwale lub naganie, ale już sofiści greccy z tzw. pierwszej sofistyki (V-IV w. p.n.e.) nadali rodzajowi epideiktycznemu szersze pole self-presentation, kładąc nacisk właśnie na widowiskowość mowy, ubierali się w purpurowe szaty rapsoda, co należy odebrać jako zabieganie w świadomości publicznej o uznanie pozycji podobnej do tej, jaką w epoce kultury oralnej pełnił poeta i rapsod, czyli pozycji wychowawcy i leadera w pouczeniu etycznym. Zob. G.B. Kerferd, The Sophistic Movement, Cambridge 1984, s. 28-29.

${ }^{30}$ Zob. Stephen Usher, Greek Oratory. Tradition and Originality, Oxford 1999, s. 299.

${ }^{31}$ Korolko Mirosław (1990), Sztuka retoryki. Przewodnik encyklopedyczny, Warszawa, s. 173. 
Długie, bo liczące 98 lat życie, Izokrates poświęcił jednej idei - zjednoczenia wszystkich Greków pod silnym berłem zdolnego przywódcy w wyprawie przeciw odwiecznemu wrogowi - Persji. W zasadzie uprawiał publicystykę polityczną, kładąc przy tym nacisk na kulturę wymowy i wyposażenie stylistyczne, tekstu. Był przy tym świadom konieczności podążania z duchem czasu, pisząc w mowie Euagoras (7) słowa:

„Postęp w zakresie sztuk i innych rzeczy dokonuje się nie za sprawą ludzi przywiązanych do tradycji, lecz tych, którzy ulepszają to, co jest i zawsze mają odwagę zmienić to, co nie jest dobre" ${ }^{, 2}$

oraz w Panegiryku (10):

„Sądzę, że największy postęp tak i innych sztuk, co kultury słowa można osiągnąć wówczas, gdy nie tylko podziwia się i czcią otacza te osoby, które położyły podwaliny pod ich rozwój, ale także tych, którzy najlepiej w obu tych dziedzinach się realizują, ${ }^{, 33}$

Połączenie w jednym hybrydycznym gatunku rodzaju epideiktycznego i politycznego, przed innowacyjnym pomysłem Izokratesa, było praktykowane w postaci gatunku epitaphios logos, mowy pogrzebowej nad marami żołnierzy poległych w walce za demokratyczne Ateny. Mowa należała do mów okolicznościowych, wygłaszana była w trakcie uroczystej państwowej ceremonii, pochówku we wspólnym grobie wszystkich wojowników, których bohaterstwo i poświęcenie dla demokratycznej ojczyzny chwalone było in corpore, przez mówcę, Ateńczyka, o nieskazitelnej opinii moralnej i zdolnościach oratorskich. Zwyczaj sięgał okresu wojen perskich, w których Ateńczycy w bardzo wysokim stopniu wzięli na swe barki obronę całej Hellady. Epitaphios logos był gatunkiem rdzennie attyckim, nieuprawianym nigdzie poza demokratycznymi Atenami, uważany jest za najbardziej skostniały formalnie gatunek starożytnej retoryki, ściśle powiązany z drobiazgowym ceremoniałem $^{34}$. Ze względu na sytuację mówca nie tylko sławił męstwo tych, którzy oddali życie za ojczyznę, ale przedstawiał ciąg przykładów mitologicznych i wydarzeń historycznych poprzedzających akt bohaterstwa poległych żołnierzy, i równocześnie chwalił ustrój demokratyczny jako ten, który zdolny jest wydać synów przedkładających obronę ojczyzny i sławę jej towarzyszącą nad własne życie. Chwaląc dumną przeszłość Aten i tych, którzy położyli podwaliny pod demokrację, mówca chwalił zalety ustroju demokratycznego, a kończył zbiorową pochwałą aktu-

\footnotetext{
${ }^{32}$ Przekład Krystyny Tuszyńskiej [w:] Oratorstwo i retoryka grecka z wyborem tekstów źródtowych. Od oralnej kultury retorycznej Homera do konceptualizacji retoryki przez Arystotelesa, Poznań 2016, s. 117.

${ }^{33}$ Ibidem.

${ }^{34}$ Celną, acz skondensowaną charakterystykę gatunku, dał George Kennedy w: The Art Persuasion in Greece, Princeton, New Jersey, 1963; obszernie gatunek opracowała Nicole Loraux, The Invention of Athens. The Funeral Oration in the Classical City, trans. A. Sheridan, New York 2006.
} 
alnie poległych żołnierzy, udzielając też rad przywódcom demokratycznego państwa, w jaki sposób otoczyć opieką starych rodziców i jakich dołożyć starań, aby młodociani synowie poległych poszli w ślady poświęcenia ich ojców. Kumulacja efektu jest tu oczywista, podobnie jak hołd składany demokracji.

W Wojnie peloponeskiej Tukidydesa przywódca demokracji, Perykles, wygłaszając epitaphios logos akcentuje niezwyczajną pozycji Aten w świecie greckim:

„Państwo nasze pozostawiamy otwarte dla wszystkich; nie zdarza się, żebyśmy wydalali cudzoziemców i nie pozwalali komuś uczyć się u nas. [...] Państwo nasze jest godne podziwu i pod innymi względami. [...] Jesteśmy jedynym narodem, który jednostkę nieinteresującą się życiem państwa uważa nie za bierną, ale za nieużytecznąa ${ }^{35}$. Zawsze sami oceniamy wypadki i staramy się wyrobić sobie trafny sąd: nie stoimy na stanowisku, że słowa szkodzą czynom, lecz że najpierw trzeba dać się pouczyć słowom, zanim się do czynów przystąpi. [...] Krótko mówiąc, twierdzę, że państwo nasze jako całość jest szkołą wychowania Hellady [...] i każda jednostka może z największą swobodą przystosować się u nas do najróżniejszych form życia i stać się przez to samodzielnym człowiekiem. [...] Potęga naszego państwa, poświadczona przez tyle wspaniałych dowodów, podziw będzie budzić u współczesnych i potomnych"36.

i następnie dodaje kilka zdań o poległych żołnierzach:

„W obronie takiego państwa polegli odważnie ci oto żołnierze, nie chcąc go stracić, w jego obronie także wszyscy pozostali przy życiu muszą być gotowi do cierpień. [...] Tym, którzy ocaleli należy życzyć, aby nie mniejszą mieli odwagę wobec nieprzyjaciela. Niech nie myślą o długich mowach pochwalnych, w których porusza się sprawy dobrze wszystkim znane, [...] ale niech pokochają państwo i pamiętają, że stworzyli je ludzie śmiali, obowiązkowi i ożywieni poczuciem honoru, którzy w razie niepowodzenia nie pozbawiali państwa swych usług i męstwa, lecz najcenniejszą ofiarę składali mu w ofierze" ${ }^{37}$.

Ostatnie przytoczone słowa można by odnieść niemal do „Ojców Założycieli” z gatunku inaugural speech.

Te dwa wybrane przykłady są świadectwem, że już w greckiej starożytności istniał gatunek, który łączył cechy mowy epideiktycznej, ze względu na doniosłą okoliczność i artystyczne wyposażenie tekstu, z mową o charakterze politycznym, której celem było podtrzymanie mężnego ducha wśród obywateli, skłonienie ich do ofiar dla wspólnego dobra i wskazanie, że nie ma większej wartości niż wspólnota w duchu demokracji.

Mowa inauguracyjna Joe Bidena miała miejsce w szczególnych okolicznościach, które wytyczyła pandemia COVID 19. Wstępujący na urząd prezydent wy-

\footnotetext{
${ }^{35}$ Nasuwa się skojarzenie ze słowami Johna F. Kennedy'ego z jego mowy inauguracyjnej: „Nie pytaj, co kraj może zrobić dla ciebie, zapytaj, co ty możesz zrobić dla kraju".

${ }^{36}$ Tukidydes, op. cit., s. 108-110 (par. 39-41).

${ }^{37}$ Idem, s. 112, par. 43.
} 
raźnie zaznacza, że do tej pory pandemia zabrała ze sobą więcej ofiar niż II wojna światowa, przypominając Amerykanom, iż ta pochłonęła ponad 400 tys. istnień amerykańskich obywateli, szerząca się pandemia - więcej. Stąd okoliczności mowy inauguracyjnej Bidena są ekstraordynaryjne: to niemal mowa wygłaszana w trakcie wojny z niewidzialnym wrogiem. Szczególnym elementem tej mowy jest wezwanie nowego prezydenta do cichej, indywidualnej modlitwy za bliskich, którzy padli ofiarą pandemii. Wniosło to do publicznej uroczystości pożądany element intymności: w taki sposób każda uczestnicząca w ceremonii osoba, jak też Amerykanie śledzący jej przebieg w Internecie czy telewizji, których liczbę szacuje się na $40 \mathrm{mln}$, przeżywała indywidualnie, osobiście, bolesny moment w życiu narodu. Ból połączył się z nadzieją, bo kwestia walki z pandemią jako obecnie najistotniejszym zagrożeniem była motywem przewijającym się przez mowę Bidena. $Z$ powodu pandemii przestrzeń komunikacyjna uległa zdecydowanej przemianie: na National Mall stanęło 200 tys. amerykańskich flag, w miejsce zazwyczaj gromadzących się obywateli, liczbę uczestniczących w ceremonii osób ograniczono do tysiąca, łącznie z gośćmi w osobach były prezydentów i byłych pierwszych dam: Georga Busha i Laury Bush, Billa Clintona i Hilary Clinton, Baracka Obamy i Michelle Obamy. Uroczystości strzegło 25 tysięcy żołnierzy, co było wynikiem krwawych zamieszek spowodowanych atakiem zwolenników Donalda Trumpa na Kapitol w dniu 6 stycznia, dwa tygodnie przed uroczystością zaprzysiężenia Bidena. Mieszkańcy Waszyngtonu, pytani przez reporterów zagranicznych o odczucia, odpowiadali, że opustoszałe ulice i cisza sprawiały wrażenie wyludnionego, niczym po jakimś kataklizmie, miasta.

Drugim elementem wyróżniającym sytuację występu Joe Bidena wśród innych wystąpień prezydentów obejmujących najwyższy urząd w USA, były rozpalone emocje na tle konfliktów rasowych po śmierci Georga Floyda. Spory na tle rasowym od zawsze towarzyszyły obywatelom amerykańskim, ale tym razem konflikt zaostrzył się do tego stopnia, że przestał być sprawą wewnętrzną Ameryki, a stał się zarzewiem wystąpień antyrasistowskich na całym świecie, zaś zamordowany Floyd symbolem nierówności społecznych w USA.

Trzecią niezwyczajną okolicznością dla wygłoszenia mowy inauguracyjnej Bidena była nieobecność na uroczystości ustępującego Donalda Trumpa, który jako pierwszy od 150 lat $^{38}$ odmówił obecności na zaprzysiężeniu swojego następcy. Odlot Trumpa helikopterem sprzed Białego Domu, kilka godzin przed ceremonią zaprzysiężenia Bidena, okazał się jednak paradoksalnie, walorem pomocnym: ten, który odmieniał zaimek ,ja” przez wszystkie przypadki, który nieustannie dzielił społeczeństwo, który wprowadził pojęcie „faktów alternatywnych” swoją nieobecnością uwolnił przestrzeń komunikacyjną, pozostawiając ją w całości swemu następcy.

\footnotetext{
${ }^{38}$ Wcześniej miało to miejsce w 1869 r. W miejsce Trupma pojawił się na uroczystości wiceprezydent, Mike Pence.
} 
Gdyby pójść tropem „przewrotu kopernikańskiego” Kanta, reprezentowanego potem przez przedstawiciela neokantowskiej szkoły marburskiej, Ernsta Cassiere$\mathrm{ra}^{39}$, należałoby uznać, że 46 Prezydent USA nie tyle wkroczył do gotowego świata przedmiotowego, ile starał się poprzez instrument, jakim jest wypowiedź językowa, pozyskać i zbudować świat przedmiotowy. Zbudował go w warunkach wojennych, stąd mowa inauguracyjna Bidena stanowi w moich oczach gatunek hybrydyczny, łączący retorykę epideiktyczną, z towarzyszącym jej artystycznym wyposażeniem tekstu, z mową polityczną, skierowaną do rozdartego narodu, który toczy wojnę z pandemią, rasizmem i jest podzielony przez wrogą demokracji retorykę nieobecnego już Trumpa.

\section{Analiza retoryczna mowy inauguracyjnej Bidena}

Mówca musi zmierzyć się z trzema podstawowymi etapami przygotowania wystąpienia, tj. z inventio, dispositio i elocutio. Dopełniają ich memoria oraz actio. Pod łacińskim pojęciem inventio, kryje się polski termin „wynalezienie”. Mówca musi mieć pomysł na mowę, wiedzieć, jak podejść do tematu. Wynaleziony materiał rozkłada proporcjonalnie do wagi i tematu w części dispositio, będącej odpowiednikiem polskiej „dystrybucji materiału retorycznego”. Każda mowa ma przynajmniej cztery części: wstęp, opowiadanie, argumentację i zakończenie. Zadaniem mówcy jest wyważenie, która część zebranego przez niego materiału i w jakiej objętości powinna znaleźć się w konkretnej części. Trzecią częścią postępowania retorycznego jest elocutio, czyli wyposażenie werbalne wynalezionego i rozdysponowanego materiału. Pod zlatynizowanym polskim terminem „elokucja” kryje się „styl”.

Co do niewerbalnych środków perswazji, należy odnotować, że Biden posługuje się w sposób bardzo umiarkowany mimiką twarzy i gestykulacją jako środkami ekspresji, co może być zarówno wynikiem wieku ${ }^{40}$, jak też osobowości samego prezydenta. Również obejmowanie tak znaczącego urzędu w Stanach Zjednoczonych wymagało pewnej powściągliwości i godności, czego dowiódł spokojnym i rzeczowym tonem wypowiedzi i psychologicznym rozłożeniem pauz oraz dyskretnym stosowaniem akcentów.

Pomysł na mowę, czyli inwencja retoryczna, polegał na zaakcentowaniu zaimka liczby mnogiej - „my” w przeciwieństwie do używanego przez jego poprzednika zaimka ,ja”. Było to świadome odwrócenie się od retoryki Trumpa, współbrzmiące $\mathrm{z}$ akcentem tolerancji religijnej, jaka pojawiła się w obudowie mowy przez wprowa-

\footnotetext{
${ }^{39}$ Ernst Cassirer (1874-1945) neokantysta, identyfikujący się ze szkołą marburską. W języku polskim dostępny przez Symbol i język, wybór i thumaczenie Bolesław Andrzejewski, Poznań 2004.

${ }^{40}$ Obserwatorom występów publicznych Bidena podczas kampanii wyborczej z pewnością nie umknął fakt, że Biden zawsze wybiegał drobnymi krokami na scenę, jakby celowo akcentując wigor ciała.
} 
dzenie dwóch wstąpień przedstawicieli Kościoła w jego różnorodności i jedności chrześcijańskiej zarazem, o czym powiem w ostatniej części artykułu. Do zaimka „my” dodał Biden dwa pojęcia ,jedność” i „demokracja”. Tę ostatnią lapidarnie i celnie scharakteryzował jako „cenną i kruchą”. Są to doskonale dobrane epitety, budzą bowiem skojarzenia z koniecznością strzeżenia, pielęgnacji i szczególnej troski.

W kwestii dyspozycji materiału należy zaznaczyć, iż w mowie okolicznościowej, według Arystotelesa ${ }^{41}$, część narracyjna zespala się z częścią argumentacyjną. W mowie zaś politycznej części narracyjnej w zasadzie brakuje lub jest ona znikoma, bo oczywista:

„Niemal każdy człowiek dążąc do spełnienia własnego celu, a ogół ludzi do spełnienia wspólnego, jedne rzeczy wybiera, innych unika. Celem tym, ogólnie mówiąc jest szczęście i to wszystko, co się na nie składa" ${ }^{\text {"42 }}$.

Zatem, uznając hybrydyczny charakter mowy inauguracyjnej Bidena, uważam, że nakreślenie zasadniczych celów etycznych i politycznych przez mówcę spełniło wymóg połączenia części narracyjnej z argumentacyjną, omówione natomiast okoliczności wygenerowały mocne przesłanie o charakterze społeczno-politycznym.

Przemówienie rozpoczął Biden ze skromnością, oświadczając, iż dzień jego zaprzysiężenia nie jest ,jego triumfem, lecz triumfem demokracji”. Jest to zręczne captatio benevolentiae, pozyskanie życzliwości audytorium, przez pokazanie wspólnych celów i zadań, jakie stoją przed narodem, którego - jak ujął to mówca „wola została wysłuchana". We wstępie znalazło się też podziękowanie dla wszystkich jego poprzedników, którzy kroczyli drogą demokracji. W ten sposób nowy prezydent stawia siebie w chlubnym szeregu innych, demokratycznych prezydentów USA, ale równocześnie bierze na swe ramiona ciężar przynajmniej dorównania poprzednikom. Jest jednak pełen optymizmu, bo doszła do głosu „odporność konstytucji i siła narodu". Biden swoim wstępem daje do zrozumienia, że czuje się poniekąd namaszczony przez naród do wypełnienia trudnej życiowej misji, wierząc w jej powodzenie.

Utrzymanie wstępu w tonie optymizmu i jedności narodu należy uznać za udane. Mówca staje $\mathrm{w}$ szeregu nie tylko $\mathrm{z}$ wielkimi poprzednikami, ale przez zaimek „my” utożsamia się z całym narodem, w chwili obecnej zatrwożonym i podzielonym, ale pod jego opieką zdolnym do przezwyciężenia trudności i wygrania wojny z pandemią.

Po wstępie mówca przystępuje do działania. Składa zapowiedź działania w czterech kwestiach: walki z pandemią i wywołanym przez nią kryzysem gospodarczym,

${ }^{41}$ Arystoteles (1376b) pisze: „Pochwała jest rodzajem mowy, która uwypukla wielkość dzielności etycznej. Przedstawione czyny muszą być więc tego potwierdzeniem. [...] Okoliczności natomiast służą uwierzytelnieniu".

${ }^{42} \mathrm{Idem}, 1360 \mathrm{~b} 5$. 
usłyszenia ,zewu od planety”, to znaczy wprowadzaniu zielonego ładu, walki z ekstremizmem międzynarodowym, rozładowania konfliktów na tle rasowym.

Biden zdaje sobie sprawę nie tylko z wielkości wyzwania, z którym zapowiada się zmierzyć, ale także $\mathrm{z}$ potrzebą jedności całego narodu dla realizacji celów. Przyjmuje zatem wobec wyzwania stanowisko pokory: „Jedność dzisiaj może brzmieć jak fantazja głupca, ale to ciągła walka między ideałem a brutalną rzeczywistością". Słowa te wybrzmiewają jak słowa realisty, a nie naiwnego idealisty. Realisty świadomego ogromu wyzwania i mobilizującego cały naród do współpracy. Jedność określa Biden „rzeczą najbardziej ulotną w demokracji”. W tej części przemówienia nowy prezydent używa figury zwanej fictio personae ${ }^{43}$, a dokładnie prozopopei, przez przytoczenie historycznych słów Abrahama Lincolna z 1863 r., z Proklamacji Emancypacji, znoszącej niewolnictwo: „Cała moja dusza jest w jedności”. Wprowadzenie postaci nieżyjącej, lecz cieszącej się autorytetem, nobilituje mowę w oczach słuchacza, a tym samym podnosi etos mówcy. Dodatkowo należałoby, moim zdaniem, dopatrywać się w przywołaniu słów Lincolna figury zwanej expolitio, która jest wariacją językową przytaczanej wypowiedzi. Ekspolicja polega na opracowaniu idei przez wariację językowego jej ukształtowania oraz wprowadzeniu sekundarnych idei należących do idei głównej ${ }^{44}$. Słowa Abrahama Lincolna padły w zgoła innych okolicznościach i miały nieco inny wydźwięk w jego ustach, nie mniej jednak zasadnicze pojęcie, to znaczy ,jedność”, okazało się przydatne w obecnym przesłaniu. Powołanie się na słowa pierwszego prezydenta USA udzieliło też godności występowi Bidena.

Nowy prezydent wskazuje słuchaczom drogę prowadzącą do jedności. Pokazuje ją, jak sam zapewnia, historia, rozum i wiara. Połączenie wiary i rozumu (fides et ratio) znane jest wyznawcom chrześcijaństwa z Encykliki papieża Jana Pawła II, ogłoszonej pod tym właśnie tytułem w 1998.

Po odwołaniu się do autorytetu Historii uosobionej we wspomnianych słowa Lincolna, Biden wprowadza do mowy kolejny autorytet moralny, w postaci słów św. Augustyna: „Ludzie są mnogością definiowaną przez wspólny obiekt ich miłości”45. Owym wspólnym obiektem miłości dla nowego prezydenta, jak i dla świętego jego Kościoła, jest Prawda. Obok Jedności staje się ona kolejnym filarem, na którym Biden buduje mowę inauguracyjną. Dodatkowo zdanie wzięte z rozważań św. Augustyna nadaje przemówieniu Bidena powagi, można je bowiem potraktować

${ }^{43}$ Fictio personae teoretycy retoryki dzielili na prozopopeję, stosowaną dla wprowadzenia osób zmarłych lub obiektów nieosobowych oraz na etopeję (ethopoiea), czyli udzielenie głosu osobom żyjącym współcześnie. Zob. Henrich Lausberg, Retoryka literacka, przełożył, opracował i wstępem poprzedził A. Gorzkowski, Bydgoszcz 2002, par. 826-829 (s. 454-456).

${ }^{44}$ Por. H. Lausberg, op. cit., par. 830-842 (s. 456-460).

${ }^{45}$ Podaję cytat za thumaczem na żywo w przekazie telewizyjnym ceremonii zaprzysiężenia nadanym przez Fakty24. W wersji Internetowej przemówienia Joe Bidena myśl jest nieco spłaszczona przez thumacza. Św. 
jako sententia. Kwintylian (VIII, 5,6) uważał, że „sentencje osiągają większą siłę wyrazu dzięki przeniesieniu ze znaczenia ogólnego do konkretnego" "46. Arystoteles (1395a 5) stał na stanowisku, że stosowanie sentencji korzystnie wypada $\mathrm{w}$ przemowach ludzi starszych wiekiem, stoi bowiem za nimi doświadczenie życiowe. Długa, systematycznie przebiegająca kariera polityczna Bidena, jak również osobiste, trudne doświadczenia życiowe, wymagające hartu ducha i siły woli, by dalej uczestniczyć w życiu politycznym i budować mosty porozumień, stanowią gwarancję efektywności posłużenia się sentencją.

Przytoczne cytaty ze słów dwóch wielkich mężów, aczkolwiek wprowadziły pożądaną dignitas, godność mowy, mogły jednak nie trafić do zróżnicowanego pod wieloma względami, w tym intelektualnym, audytorium. Zatem Biden wypowiada proste i zrozumiałe dla każdego zdanie, oparte na ogólnodostępnej mądrości życiowej: „Nie wiemy, jakie karty rozda nam Los, takie jest życie”. Tym samym zwraca się do ludzi niechętnie czy mniej pozytywnie nastawionych do jego prezydentury. „Dziś Los dał mnie dobrą kartę, zrobię wszystko, aby jej nie zmarnować” - można by dopowiedzieć do słów Bidena. Tym samym bierze też pod uwagę sytuację, że w kolejnym rozdaniu zatriumfują ludzie teraz mu niechętni, co jednak sprawia, że stojące przed nim wyzwanie jest tym bardziej warte walki. Tym zabiegiem retorycznym pozyskuje sobie publiczność, mamy do czynienia z kolejnym capatatio benevolentiae. Biden daje prosty przekaz: ,jestem jednym z was, dziś Los uśmiechnął się do mnie". Przekaz ten jest także wprowadzeniem figury personifikacji Losu, który „rozdaje karty”.

Nowy prezydent, świadomy podzielenia narodu, zwraca się z apelem do tych, którzy na niego nie głosowali: „Zobaczcie, kim jestem w sercu, usłyszcie mnie!”. Dzięki temu apelowi sprawia wrażenie człowieka przystępnego i dostępnego poznaniu przez obywateli. Nie chowa się za kurtyną wielkiej władzy, jaką de facto daje mu urząd. Zręcznie wykorzystuje kontradykcję w stosunku do bezpośredniego poprzednika, który odmieniał w przemówieniach zaimek ,ja” przez wszystkie przypadki. W tym obszarze wybrzmiewa jeszcze aluzja do nowomowy Trumpa: Biden stwierdza, że on „stawia na fakty, a nie na fakty alternatywne" ${ }^{\text {"47 }}$.

W segmencie mowy, w którym zbliża się do rodaków, stosuje tryb hortativus w postaci trikolonu: (1) zacznijmy znów słuchać siebie nawzajem, (2) zacznijmy dostrzegać siebie nawzajem, (3) zacznijmy szanować siebie nawzajem. Trikolon to trzy połączone zdania, które odpowiadają sobie troistym porządkiem ${ }^{48}$. Oczywiście,

${ }^{46}$ Przekład K. Bociana podany za: H. Lausberg, op. cit., par. 874 (s. 473).

${ }^{47}$ Sformułowanie „fakty alternatywne” pojawiło się w retoryce Trumpa w momencie uświadomienia sobie faktu przegranej w wyborach prezydenckich. Nie chcąc pogodzić się z takim wynikiem wprowadzał i on i jego rzecznicy pojęcie „faktów alternatywnych” i budząc tym samym niepokoje społeczne.

${ }^{48}$ Definicja wg Carmen de figuris vel schematibus, Halm; przekład za thumaczeniem Gorzkowskiego w: H. Lausberg, op. cit., par.733 (s.406). 
w językach nowożytnych, z powodu barku iloczasu, trudno czy wręcz rzeczą niemożliwą jest oddanie metrycznej jakości sylab w każdym z trzech kolonów. Nie mniej jednak trikolon niósł zawsze silny ładunek emotywny, polegający na powtórzeniu tej samej myśli trzykrotnie, w tym samym porząaku składniowym. Dodatkowo emotywność wzmaga ujęcie tych myśli w asyndeton, czyli zdanie bezspójnikowe.

Augustyn wyraźnie mówi i „mnogości” ludzkiej i wspólnym tej mnogości jednym obiekcie miłości, jakim powinna być prawda.

Arystoteles chwali asyndeton jako posiadający właściwość powiększania rzeczy (1414a 1) oraz środek „uzyskiwania efektów dramatycznych” (1413b 20). Efekt mówca powiększa intonacją, zatem do figury elokucyjnej należy dodać element niewerbalnych środków przekonywania, tzn. grę aktorską. Biden, jak wspomniałam, jest dość oszczędny w mimice i gestykulacji, jednak spokojny, a zarazem obdarzony siłą głos i umiejętne rozłożenie akcentów sprawiły, że osiągnął wymagany efekt emotywny. Nie bez znaczenia jest też zastosowanie trybu coniunctivus w jego odmianie woluntatywnej jako coniunctivus hortativus, wyrażający wezwanie, stosowany w 1 osobie liczby mnogiej ${ }^{49}$. Tym samym Biden stawia przed całą społecznością amerykańską te same wezwania, utrzymane $\mathrm{w}$ duchu wzajemnego porozumienia i zrozumienia drugiej jednostki.

Dokonując smutnego bilansu rzeczywistości zastanej u progu prezydentury, Biden wytacza potężne działo w postaci autorytetu Biblii, cytując słowa: „Przejdziemy przez czas mroku razem”. Zapowiedź wspólnego, ramię w ramię, przejścia przez trudny czas ma wymiar obietnicy złożonej narodowi przed Bogiem. Słowa Bidena świadczą o zrozumieniu historycznego momentu, w jakim obejmuje najwyższy urząd w Stanach Zjednoczonych.

Widoczne jest to $\mathrm{w}$ zapowiedzi osądu Historii, sformułowanym przez prezydenta w postaci trzech następujących po sobie kaskadowo pytań retorycznych dotyczących wspólnych działań w czasie narastającego kryzysu epoki: Czy sprostamy temu? Czy wyjdziemy zwycięsko z tego mrocznego i trudnego okresu? Czy wypełnimy nasze zobowiązania i przekażemy naszym dzieciom nowy lepszy świat? Mają one charakter pytań czysto emotywnych, a dokładniej należą do erotema (interrogatio), ,zapytania”, w którym trzeba wybrać pomiędzy zaprzeczeniem a potwierdzeniem („tak” lub „,nie”), przy założeniu, że odpowiedź drugiej strony jest oczywista ${ }^{50}$.

Zręcznym zabiegiem retorycznym, ukierunkowanym na pathos audytorium, jest wspomniane już wezwanie do wspólnej, choć cichej modlitwy. Można w nim dopatrzyć się cech obsecratio ${ }^{51}$, która należy do figur zorientowanych na publiczność, o wysokim stopniu intensywności emocjonalnej. Zestawienie pytań retorycznych, niosących w zasadzie wezwania stojące przed obecnym pokoleniem, nakierowane na

\footnotetext{
49 Auerbach, Marian, Golias Marian, (1985), Gramatyka grecka, Warszawa, s. 190.

${ }^{50}$ Odnośnie interrogatio zob. H. Lausberg, op. cit., par. 767-770.

${ }^{51}$ Obsecratio, czyli zaklinanie jest błagalną prośbą skierowaną do ludzi, niekiedy też do bogów.
} Zob. H. Lausberg par. 760, (s. 418). 
przyszłość i cicha modlitwa za tych, których zabrała pandemia, pokazują pewną ciągłą linię czasu: tamci odeszli i należą już do przeszłości, przyszłość stanowią nasze dzieci, my jesteśmy odpowiedzialni za czas obecny. I jeśli go zmarnujemy, przyszłe pokolenia nam tego nie wybaczą. Bliskość modlitwy za zmarłych i pytań retorycznych o osąd Historii wydany wobec obecnego pokolenia daje doskonały efekt psychologiczny. Jest wyrazem posiadania przez mówcę talentu psychagogicznego ${ }^{52}$.

Znajomość zasad rządzącym przekazem retorycznym Biden potwierdza nadto kilkakrotnie stosowanymi antytezami: (1) nadzieja, a nie strach; (2) miłość, a nie nienawiść; (3) jedność, a nie podziały. Antyteza (antithesis) chwalona była już przez starożytnych jako narzędzie służące wyostrzeniu pojęć, contrarium (lub: oppositio). $\mathrm{Z}$ punktu widzenia stylistycznego antyteza należy do figurae sententiae, to znaczy porządkuje artystycznie syntaksę, ale jest też środkiem argumentacyjnym ${ }^{53}$.

Jakby wyjęte wprost w retoryki Tukidydesa brzmi zdanie: „Ameryka jest wielka nie przykładem siły, lecz siłą przykładu". Prócz efektownego przestawienia pojęć mamy tu do czynienia z figurą retoryczną zwaną synekdochą, pars pro toto. Biden ma na myśli Amerykanów jako zespół obywateli zjednoczonych wspólnymi celami i zasadami postępowania, ale zamiast powiedzieć „Amerykanie są wielcy”, wprowadza Amerykę, dodatkowo nadając jej znamiona personifikacji, wyposaża ją bowiem w moc sprawczą.

Kilkakrotnie nowy prezydent stosuje apostrofy, zwracając się do słuchaczy: „Moi rodacy, Amerykanie”, co nadaje mowie koloryt inwokacyjny.

Mowę inauguracyjną Biden kończy typowo, zarówno dla mowy okolicznościowej, jak też zgodnie z prawami retoryki politycznej uprawianej przez największego mówcę starożytnej Grecji, Demostenesa. Demostenes, płomienny i dynamiczny autor Filipik, jako mistrz trzech stylów w mocnych słowach oddawał ethos mówcy, wolę działania, wierność szlachetnej idei, ale też chłodny pragmatyzm i realizm. Zwyczajem jego było zamykać przemówienia polityczne pogodnym akcentem, życzeniami pomyślności, błogosławieństwa, czasami słowami modlitwy ${ }^{54}$. Podobnie zachował się w swoim wystąpieniu inauguracyjnym Biden: wezwał do wzajemnego sobie oddania i oddania krajowi oraz zastosował tradycyjną formułę wystąpień prezydenckich w USA: Niech Bóg błogosławi Amerykę! ${ }^{55}$ Niech Bóg chroni naszych żołnierzy!

${ }^{52}$ Gr. psychagogia - prowadzenie dusz zgodnie z oczekiwaniami mówcy. W starożytności greckiej wprowadzona jako postulat retoryczny przez Platona ustami Sokratesa w dialogu Fajdros (271d): piszący i wygłaszający mowy powinni poznać indywidualne dusze swoich słuchaczy, jeśli przyjąć, że moc mowy służy oddziaływaniu na duszę.

${ }^{53}$ Zob. Kwintylian, V, 11, 31 jako narzędzie argumentacyjne.

${ }^{54}$ Turasiewicz, Romuald (1991), Demostenes. Wybór mów, przekład i opracowanie, Ossolineum, Wrocław, s. CI-CII oraz CV.

${ }^{55}$ Formuła „God Bless America”, znajdująca się nawet na amerykańskich bilbordach, pochodzi z patriotycznej pieśni Irvinga Berlina. 
Przez całą mowę, reprezentującą hybrydyczny charakter, łączący retorykę okolicznościową z polityczną, przebija optymizm. Biden utwierdza audytorium w przekonaniu, że choć Ameryka została poddana próbie (i to nie pierwszy raz w historii), wyszła z niej zwycięsko, bo postawiła na demokrację, jedność i prawdę, a one stanowią niezbywalny fundament dobrze, i dla dobra wszystkich, sprawowanej władzy.

\section{Reżyseria spektaklu protagonisty Bidena}

Wśród koncepcji dotyczących traktowania inaugural speech jako spektaklu dla szerokiej publiczności, wysuwają się na czoło poglądy Douglasa Kellenera z jego książki Media Spectacle (2003) oraz poglądy Guya Deborda zawarte w książce Spoteczeństwo spektaklu (pol. przekład 2006). Bendrat dając syntetyczny opis koncepcji D. Kellnera zauważa, że korporacyjny charakter nowych mediów (Internet) i globalnej ekonomii skutkuje rozwojem nowych form technokratyzmu i technokultury, co generuje dostrzeżenie w mowie inauguracyjnej prezydenta USA już nie tylko spektaklu, ale ,inforozrywki” ${ }^{56}$, ponieważ kultura medialna, mnożąc coraz bardziej wyrafinowane spektakle, przyciąga coraz więcej odbiorców, przez co umacnia swoją pozycję (i zyski). Dominacja przekazu medialnego w trakcie kampanii wyborczej Bidena i Trumpa została dodatkowo wymuszona sytuacją pandemiczną. Podobnie, akt zaprzysiężenia nowego prezydenta $\mathrm{i}$ wygłoszenie przez niego mowy inauguracyjnej miało wymiar typowo medialny $\mathrm{z}$ tego samego powodu. Zainteresowanie przejęciem władzy przez Bidena było ogromne, nie tylko w Stanach Zjednoczonych, ale na całym świecie, do czego niewątpliwie przyczynił się niechlubny niedawny atak na Kapitol zwolenników Trumpa, kwestionowanie przez niego do końca wyników wyborów prezydenckich, wreszcie w sposób otwarty zamanifestowana niechęć wobec następy przez odmówienie udziału w ceremonii i opuszczenie Waszyngtonu na niespełna pięć godzin przed planowaną uroczystością. W oglądalności spektaklu zaprzysiężenia udział miały także mechanizmy ludzkiej psychiki, zarówno pozytywne, co negatywne, w tym najzwyklejsza ludzka ciekawość. Spektakl medialny z Bidenem jako jego protagonistą był nośnikiem ideologii i został starannie wyreżyserowany, tak aby słowa nowego prezydenta znalazły odpowiednik w jego artystycznej obudowie. Nie bez znaczenia symbolicznego pojawił się też artefakt w postaci Biblii, na którą złożył przysięgę Biden, trzymanej w rękach przez jego małżonkę i należącej do rodziny Bidenów od 150 lat. Posłużenie się tym artefaktem przez Bidena niosło jasny, doniosły przekaz - kontynuacji tradycji i stabilności. A ta ostatnia jest potrzebna Stanom Zjednoczonym w tym momencie historycznym nie tylko w wymiarze medialno-rozrywkowym, ale jako całkiem realny element ,amerykańskiego snu".

\footnotetext{
${ }^{56}$ A. Bendrat, op. cit., s. 194; pojęcie infotainment.
} 
46 Prezydent USA umieścił swoją mowę niejako w kompozycji ramowej. Ramy jej stanowiły wystąpienia dwóch osób duchownych: na rozpoczęcie ceremonii jezuity, o. Leo O’Donovana ${ }^{57}$, byłego prezydenta Uniwersytetu Georgetown, na zakończenie zaś przedstawiciela Kościoła Metodystów, najliczniej reprezentowanego w USA. Usytuowanie własnej mowy między dwiema, znacznie krótszymi, mowami duchownych, będących przedstawicielami różnych odłamów chrześcijaństwa, jest pierwszym sygnałem tolerancji i poszanowania odmienności wyznaniowej Amerykanów, wysłanym obywatelom przez nowego prezydenta. Tolerancja wobec tak intymnej sfery ludzkiego życia, jaką jest wyznawana religia, świadczy o poziomie kultury osobistej Bidena. Tolerancja dotycząca poszanowania życia prywatnego jednostki stanowi piękny spadek po demokracji ateńskiej z najlepszego okresu jej rozwoju. W cytowanym już epitaphios logos Peryklesa, zamieszczonym przez Tukidydesa, przywódca demokracji zwięźle, ale też dosadnie, przedstawia osiągnięcia demokratycznego ustroju Aten:

„Nasz ustrój polityczny [...] nazywa się demokracją, ponieważ opiera się na większości obywateli, a nie na mniejszości. W sporach prywatnych każdy obywatel jest równy w obliczu prawa; jeśli zaś chodzi o znaczenie, to jednostkę ceni się nie ze względu na jej przynależność do pewnej grupy, lecz ze względu na talent osobisty, jakim się wyróżnia; nikomu też, kto jest zdolny służyć ojczyźnie, ubóstwo albo nieznane pochodzenie nie przeszkadza w osiągnięciu zaszczytów. W naszym życiu państwowym kierujemy się zasadą wolności. W życiu prywatnym nie wglądamy z podejrzliwą ciekawością w zachowanie się naszych współobywateli, [...] i nie rzucamy w jego stronę owych pogardliwych spojrzeń, które wprawdzie nie wyrządzają szkody, ale ranią"58.

Perykles podkreśla równe szanse, stojące przed obywatelami Aten, bez względu na ich pochodzenie. Ten atut demokracji wykorzystuje też w swojej mowie Biden zwracając uwagę na fakt, że po raz pierwszy w historii Stanów Zjednoczonych czarnoskóra kobieta zostaje zaprzysiężona na wiceprezydenta.

Tym samym użycie przez Bidena w inaugural speech pojęć „tolerancja” i „,równość ludzi" zyskało sankcję za sprawą oprawy duchowej. Dla Amerykanów religia i wiara w Boga jest konkretnym elementem ich codziennego życia, zatem otwarcie uroczystości przez modlitwę jezuity i zakończenie jej przez pastora anglikańskiego stanowiło wiarygodny dowód na niezbędność tolerancji w wielkim i zróżnicowanym kulturowo kraju.

Do oprawy ceremonii należą także występy artystów, na początku i w zakończeniu. Hymn Stanów Zjednoczonych Ameryki odśpiewała Lady Gaga, ubrana w sukienkę w kolorach flagi amerykańskiej: czerwonym i ciemnoniebieskim. Dopasowana góra miała kolor ciemnoniebieski, drapowany i widowiskowy dół sukienki -

\footnotetext{
${ }^{57}$ Joe Biden jest wyznania rzymsko-katolickiego.

${ }^{58}$ Tukidydes, Wojna peloponeska II, 38; Z języka greckiego przełożył, przedmową i przypisami opatrzył Kazimierz Kumaniecki, Warszawa 1988, s. 107.
} 
czerwony. Strój słynnej piosenkarki miał wymiar symboliczny i tym samym wpisuje się w rozpatrywanie komunikatu retorycznego w przestrzeni publicznej. Zaprzysiężenie nowego prezydenta odbywa się w konkretnej przestrzeni, która swojej rangi udziela również osobom aktywnie w niej działającym ${ }^{59}$. Przestrzeń publiczna jest bogatym środowiskiem komunikacyjnym, jest pewnym wytworem społecznym, ale też - wedle koncepcji Kanta - funkcjonuje jako odrębna własność ludzkiej świadomości, dokładniej - jako „forma naszej zmysłowej władzy przedstawiania siebie”,60. Występ Lady Gagi, jak i wszystkich artystów uświetniających ceremonię, z jednej strony był definiowany przez funkcję przestrzeni publicznej - stopnie Kapitolu, z drugiej strony sama artystka zamanifestowała ubiorem poczucie identyfikacji z flagą amerykańską. Warto zauważyć wszechobecność w ogóle flagi narodowej w przestrzeni życiowej zwykłego Amerykanina: powiewa ona nie tylko przed budynkami publicznymi, ale przyozdabia domy i samochody obywateli ${ }^{61}$.

Po Lady Gadze wystąpiła Jennifer Lopez, wykonując dwie pieśni This Land Is Yours Land i America the Beautiful, oraz wypowiadając w języku hiszpańskim fragment formuły lojalności: „Jeden naród, niepodzielny przed Bogiem, oferujący każdemu wolność i sprawiedliwość" ${ }^{62}$. Lopez użyła języka hiszpańskiego, który ze względów historycznych konkwisty, jest świadectwem ,jedności niepodzielnego

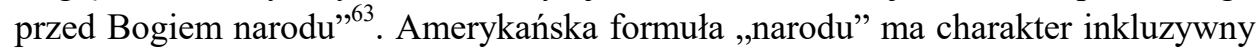
- w procesie historycznym trwale uniezależniła się od identyfikacji etnicznej, jednocześnie ściśle związując się z amerykańskim republikanizmem. Wg R. Prostaka:

„amerykańskość jest zasadniczo rozumiana jako wspólne przywiązanie do określonych ponadhistorycznych (aczasowych) norm moralnych oraz zasad konstytucjonalnych opartych na niekwestionowanych wartościach, które legły u podstaw amerykańskiego projektu ustrojowego" ${ }^{\circ}$.

Trzecim artystą uświetniającym uroczystość inauguracyjną był Garth Brooks ${ }^{65}$, który zaśpiewał starą pieśń religijną, protestancki hymn, Amazing Grace, traktowany szczególnie w Stanach Zjednoczonych jako wyraz sprzeciwu wobec terroru

${ }^{59}$ Skrupulatne analizy przestrzeni publicznej w kontekście komunikatu retorycznego oraz niewerbalnych środków perswazji znajdują się w książce Joanny Puppel (2014) Obecność i rola gestów rytualnych w przestrzeni publicznej, Poznań, s. 37-52.

${ }^{60}$ Cytat z I. Kanta za J. Puppel, op. cit., s. 39.

${ }^{61}$ Prostak Rafał, (2010), Patriotyzm po amerykańsku, „Znak”, (wrzesień). Warto nadmienić, że zagadnieniem wszechobecności flagi państwowej w przestrzeni publicznej zajął się Michael Billing w głośnej książce Banal Nationalism.

${ }^{62}$ Formuła Lojalności.

${ }^{63}$ Językiem hiszpańskim posługuje się ponad $48 \mathrm{mln}$ obywateli; jedynie Meksyk obecnie wyprzedza USA w mianie największego kraju hiszpańskojęzycznego.

${ }^{64}$ R. Prostak, op. cit.

${ }^{65}$ Garth Brooks jest wokalistą, na co dzień łączącym muzykę country i rocka, zdobywcą wielu nagród, w tym prestiżowej Grammy (dwukrotnie). 
i przemocy. Sam Brooks na zakończenie występu zaakcentował własny wybór utworu na ceremonię. Wykonanie tej znanej protestanckiej pieśni miało charakter symboliczny, jedności wszystkich Amerykanów, niezależnie od koloru skóry czy wyznania. Amazing Grace to hymn autorstwa Johna Newtona ${ }^{66}$, który pod koniec burzliwego życia został duchownym i zdecydowanie opowiedział się przeciw niewolnictwu. Pieśń stała się podwójnym symbolem w Stanach: obok symbolu sprzeciwu wobec niewolnictwa (stąd czarnoskóra publiczność zgromadzona na ceremonii inauguracji Bidena zareagowała łzami wzruszenia na jej dźwięk), zyskała nową wymowę po islamskich atakach terrorystycznych z dnia 11 września 2001 r., stając się pieśnią wykonywaną na uroczystościach żałobnych. Wybór utworu przez Brooksa na ceremonię zaprzysiężenia demokraty, Bidena, nie był przypadkowy.

Zakończenie oprawy artystycznej należało do afroamerykańskiej poetki, dwudziestodwuletniej Amandy Gorman ${ }^{67}$, która przedstawiając się jako „chuda dziewczynka z pokolenia niewolników” zarecytowała napisany na tę szczególną okoliczność poemat The Hill We Climb. Słowem, które definiuje ów poemat, jest Nadzieja. Amanda mówi o zwycięstwie, jakie osiąga się nie dzięki ostrzom, lecz dzięki mostom. Poemat zaczyna się od słów: „Gdy nadchodzi dzień, zadajemy sobie pytanie, gdzie zanieść światło w tym niekończącym się cieniu?” " ${ }^{8}$. Zamknięcie oprawy artystycznej ceremonii przez czarnoskórą poetkę wpisuje się w tradycję, jaką zapoczątkował Bill Clinton, na inauguracji którego wystąpiła Maya Angelou w 1993 r., i kontynuowaną przez Baracka Obamę w 2009 r., gdy ten zaprosił Afroamerykankę Elizabeth Alexander.

Amanda była ubrana w żółty płaszcz od Prady, a wybór intensywnego koloru podyktowany został dawniejszą, przypadkową uwagą dr Jill Biden, małżonki nowego prezydenta, iż Amandzie do twarzy w żółtym kolorze. Panna Gorman dobrze zapamiętała i wykorzystała kobiecą poradę stylistyczną. Dr Jill Biden, obecnie już Pierwsza Dama USA ${ }^{69}$, poprosiła miesiąc wcześniej Amandę o napisanie wiersza na uroczystość zaprzysiężenia jej męża. Poetka pisząc utwór inspirowała się, jak wyznaje, przemówieniami Abrahama Lincolna i Martina Luthera Kinga. Żadna z tych dwu kobiet nie mogła wówczas przypuszczać, jak bardzo aktualny w swojej wymowie stanie się poemat o Nadziei, The Hill We Climb.

Wymienione występy: dwóch duchownych różnych odłamów chrześcijaństwa, trzech wykonawców pieśni uświetniających uroczystość, wreszcie afroamerykań-

${ }^{66}$ Hymn został opublikowany w zbiorze „Olney Hymns” w 1779, napisany zaś prawdopodobnie w 1772, kiedy autor przeżył ocalenie z burzy morskiej, podczas służby na statku przewożącym niewolników.

${ }^{67}$ Amanda Gorman jest dwukrotną laureatką konkursów poetyckich w USA: w 2014 r. zdobyła tytuł Youth Poet Laureate of Los Angeles, a w 2017 tytuł National Youth Poet Laureate.

${ }^{68}$ Cytat wg „Oko Press”, dostęp 30.01.2021.

${ }^{69}$ Dr Jill Biden poznała talent Afroamerykanki w 2019, słuchając w bibliotece Kongresu jej poematu „In this Place: an American Lyric”. 
skiej młodziutkiej i utalentowanej poetki, stanowiły nie tylko oprawę ceremoniału zaprzysiężenia Bidena na 46. Prezydenta USA, ale też treścią i widowiskowością wsparły przekaz retoryczny, zawarty w jego mowie inauguracyjnej. Artefakt w postaci wiekowej Biblii oraz „opróżnienie” przestrzeni komunikacyjnej przez Trumpa miały także swój udział w udanym spektaklu, śledzonym w mass mediach na całym świecie.

\section{Bibliografia}

Andrzejewski, B. 2012. "HOMO COMMUNICATIVUS w świetle nowożytnego empiryzmu angielskiego". W zbiorze: Lingua: nervus rerum humanarum. Essays in Honour of Professor Stanistaw Puppel on the Occasion of his 65th Birthday, Poznan;

Aristoteles. 1975. Art of Rhetoric. ang. thumaczenie Freese, J.H. Cambridge: Harvard University Press.

Arystoteles 1988. Retoryka. Poetyka. Przeł., wstępem i komentarzem opatrzył Podbielski, H. Warszawa: Państwowe Wydawnictwo Naukowe.

Auerbach, M. i M. Golias. 1985. Gramatyka grecka. Warszawa: Wydawnictwo PWN.

Bendrat, A. 2016. Mowa jest złotem. Amerykański prezydent i retoryka. Olsztyn: Wydawnictwo IBL PAN

Campbell, K. i K. Jamieson. 2008. Presidents creating presidency: deeds done in words. Chicago: University of Chicago Press.

Eco, U. 1996. Struktura nieobecna. Przeł. Weisberg, A i P. Bravo. Warszawa: Wydawnictwo KR.

Hadot, P. 1984. Arts liberaux et philosophie dans la pensie antique. Paris: Etudes augustiniennes.

Hardie, W.F.R. 1968. Aristotle's Ethical Theory. Oxford: Oxford University Press.

Kerferd, G.B. 1984. The Sophistic Movement. Cambridge: Cambridge University Press.

Korolko, M. 1990. Sztuka retoryki. Przewodnik encyklopedyczny. Warszawa: Wiedza Powszechna.

Lausberg, H. 2002. Retoryka literacka. Przeł., wstępem i komentarzem opatrzył Gorzkowski, A. Bydgoszcz: Homini.

Prostak, R. 2010. „Patriotyzm po amerykańsku”. Znak 664.

Puppel, J. 2014. Obecność i rola gestów rytualnych w przestrzeni publicznej. Poznań: Wydawnictwo Naukowe UAM.

Tukidydes. 1988. Wojna peloponeska. Przeł. i wstępem opatrzył Kumaniecki, K. Warszawa: Czytelnik.

Turasiewicz, R. 1975. Od ethosu do ethopoii. Studia z antycznej terminologii krytyczno-literackiej u Dionizjusza z Halikarnasu. Warszawa, Kraków: Państwowe Wydawnictwo Naukowe.

Turasiewicz, R. 1988. Demostenes. Wybór mów, przełożył i opracował, Warszawa;

Tuszyńska-Maciejewska, K. 2002. „Arystotelesowskie wskazówki dla aktorów, czyli o przenikaniu się sztuk". Meander 5/6. 395-402.

Tuszyńska, K. 2016. Oratorstwo i retoryka grecka z wyborem tekstów źródtowych. Od oralnej kultury greckiej do konceptualizacji retoryki przez Arystotelesa. Poznań: Wydawnictwo Naukowe UAM.

Usher, S. 1999. Greek Oratory. Tradition and Originality. Oxford:

Ziomek, J. 1990. Retoryka opisowa. Wrocław: Ossolineum. 